\title{
Biodegradation-Mediated Enzymatic Activity-Tunable Molybdenum Oxide Nanourchins for Tumor-Specific Cascade Catalytic Therapy
}

\author{
Xi Hu, ${ }^{\dagger,+,,, o, \#, \perp}$ Fangyuan Li, ${ }^{\dagger, \downarrow, \S, \perp}$ Fan Xia, ${ }^{\dagger,+, \perp}$ Xia Guo, ${ }^{\dagger, \dagger}$ Nan Wang, ${ }^{\dagger}$ Lili Liang, ${ }^{\dagger}$ Bo \\ Yang, ${ }^{\ddagger}$ Kelong Fan, ${ }^{\Delta, \nabla}$ Xiyun Yan, ${ }^{\Delta, \nabla}$ Daishun Ling, ${ }^{*} \dagger, \ddagger, \S, o$
}

$\dagger$ Institute of Pharmaceutics, College of Pharmaceutical Sciences, Zhejiang University, Hangzhou 310058, China

\$ Zhejiang Province Key Laboratory of Anti-Cancer Drug Research, College of Pharmaceutical Sciences, Zhejiang University, Hangzhou 310058, China.

$\S$ Hangzhou Institute of Innovative Medicine, College of Pharmaceutical Sciences, Zhejiang University, Hangzhou 310058, China

${ }^{\circ}$ Key Laboratory of Biomedical Engineering of the Ministry of Education, College of Biomedical Engineering \& Instrument Science, Zhejiang University, Hangzhou 310058, China \# The First Affiliated Hospital, College of Medicine, Zhejiang University, Hangzhou 310003, China

${ }^{\Delta}$ CAS Engineering Laboratory for Nanozyme, Key Laboratory of Protein and Peptide Pharmaceutical, Institute of Biophysics, Chinese Academy of Sciences, 15 Datun Road, Beijing 100101, China

$\nabla$ Academy of Medical Sciences, Zhengzhou University, 40 N Daxue Road, Zhengzhou 450052, China

$\perp$ These authors contributed equally to this work.

Correspondence and requests for materials should be addressed to D.L. (email: lingds@zju.edu.cn) 


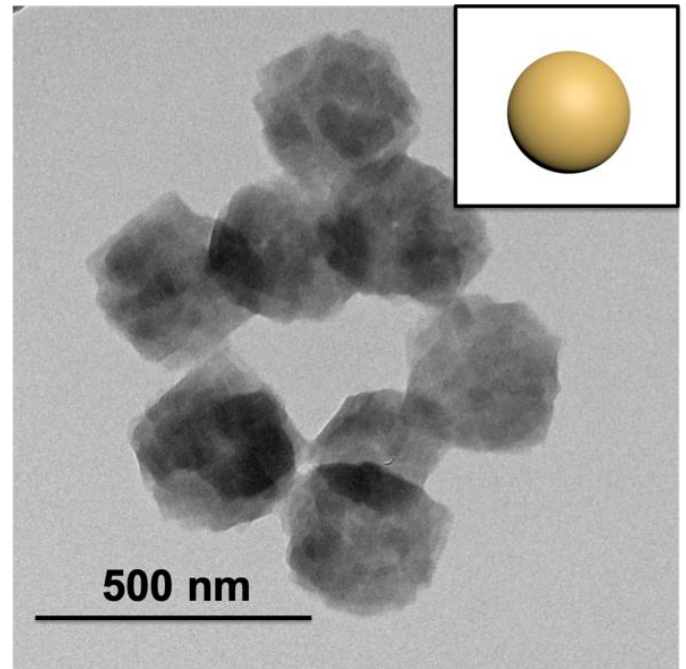

Figure S1. The TEM image of solid sphere-like $\mathrm{MoO}_{3-\mathrm{x}}$ nanoparticles (as a pre-heating product) obtained by uniformly heating the reactants at $100{ }^{\circ} \mathrm{C}$ for $10 \mathrm{~min}$.
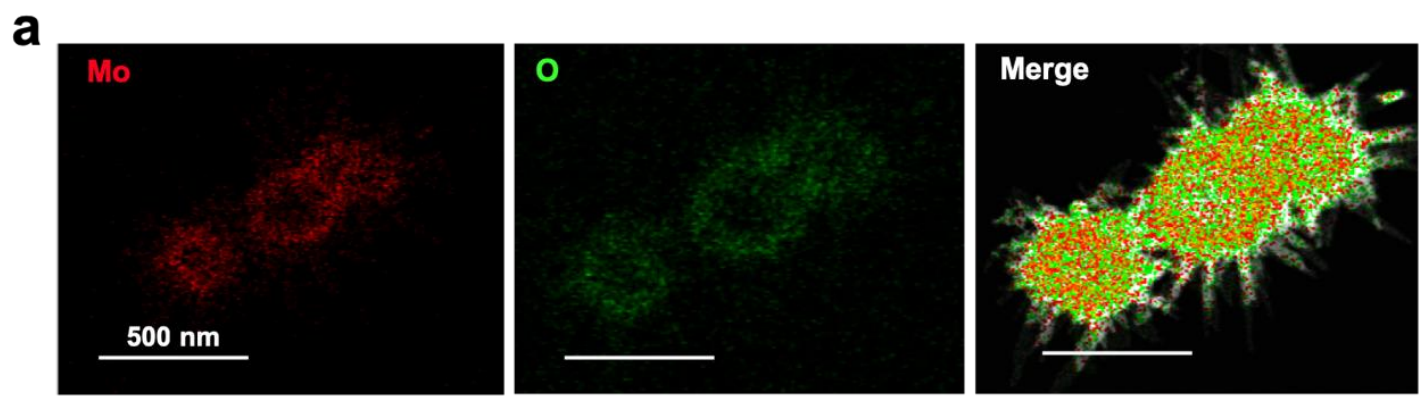

b

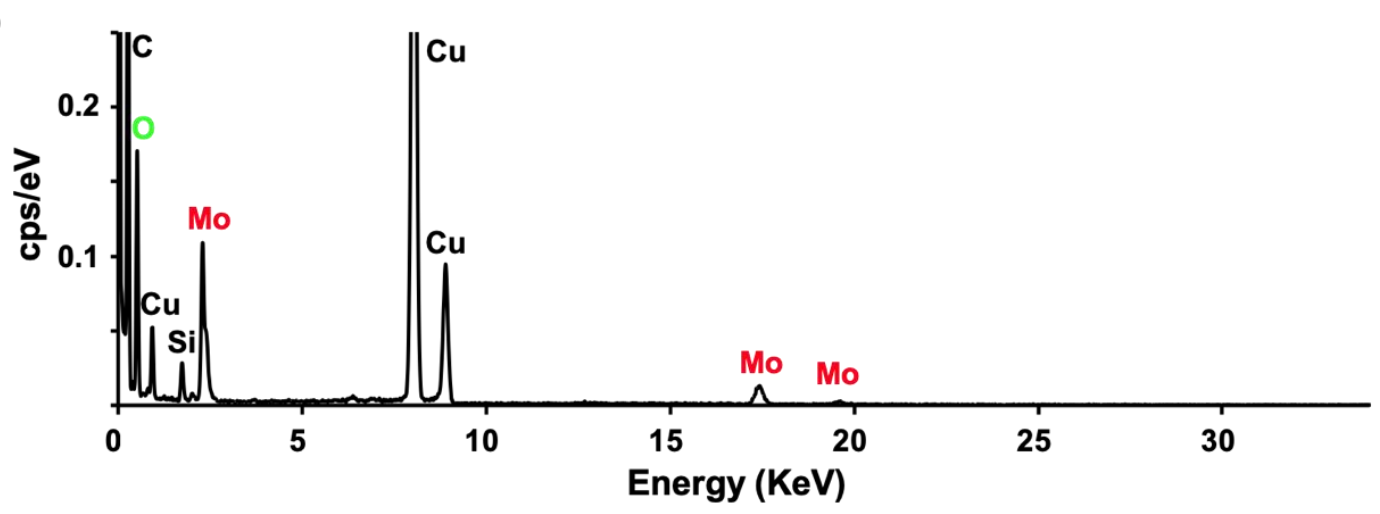

Figure S2. (a) Elemental analysis and (b) EDS spectrum of $\mathrm{MoO}_{3-\mathrm{x}} \mathrm{NUs}$. The $\mathrm{Cu}, \mathrm{C}$, and $\mathrm{Si}$ in EDS spectrum come from the ultra-thin carbon-coated copper mesh grid. 


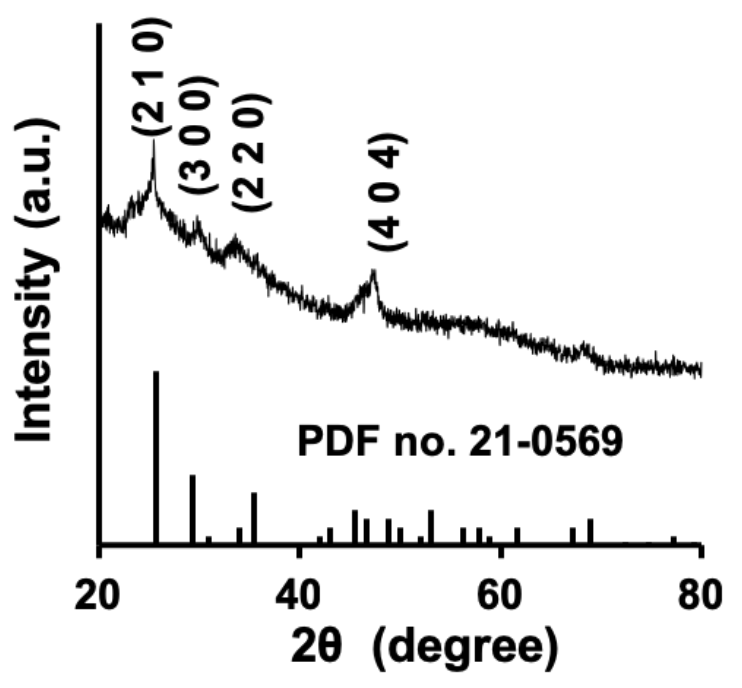

Figure S3. The XRD pattern of $\mathrm{MoO}_{3-\mathrm{x}} \mathrm{NUs}$.

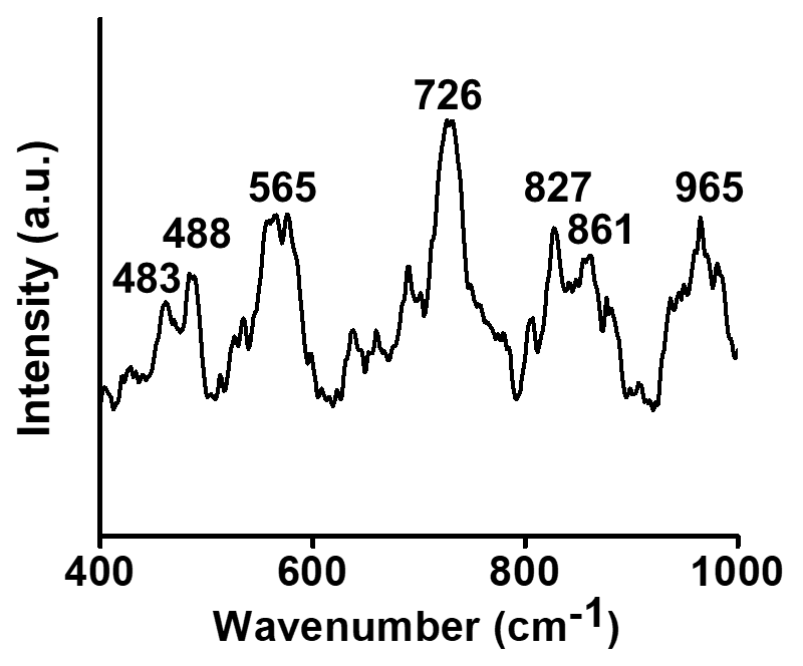

Figure S4. The Raman spectrum of $\mathrm{MoO}_{3-\mathrm{x}}$ NUs. The peaks of doubly coordinated bridging oxygen (Mo2-O) and triply coordinated oxygen (Mo3-O) are shifted from $821 \mathrm{~cm}^{-1}$ to $861 \mathrm{~cm}^{-}$ ${ }^{1}$ and $666 \mathrm{~cm}^{-1}$ to $726 \mathrm{~cm}^{-1}$, respectively, indicating the implantation of $\mathrm{H}^{+}$in $\mathrm{MoO}_{3-\mathrm{x}} \mathrm{NUs} .{ }^{1-3}$ 

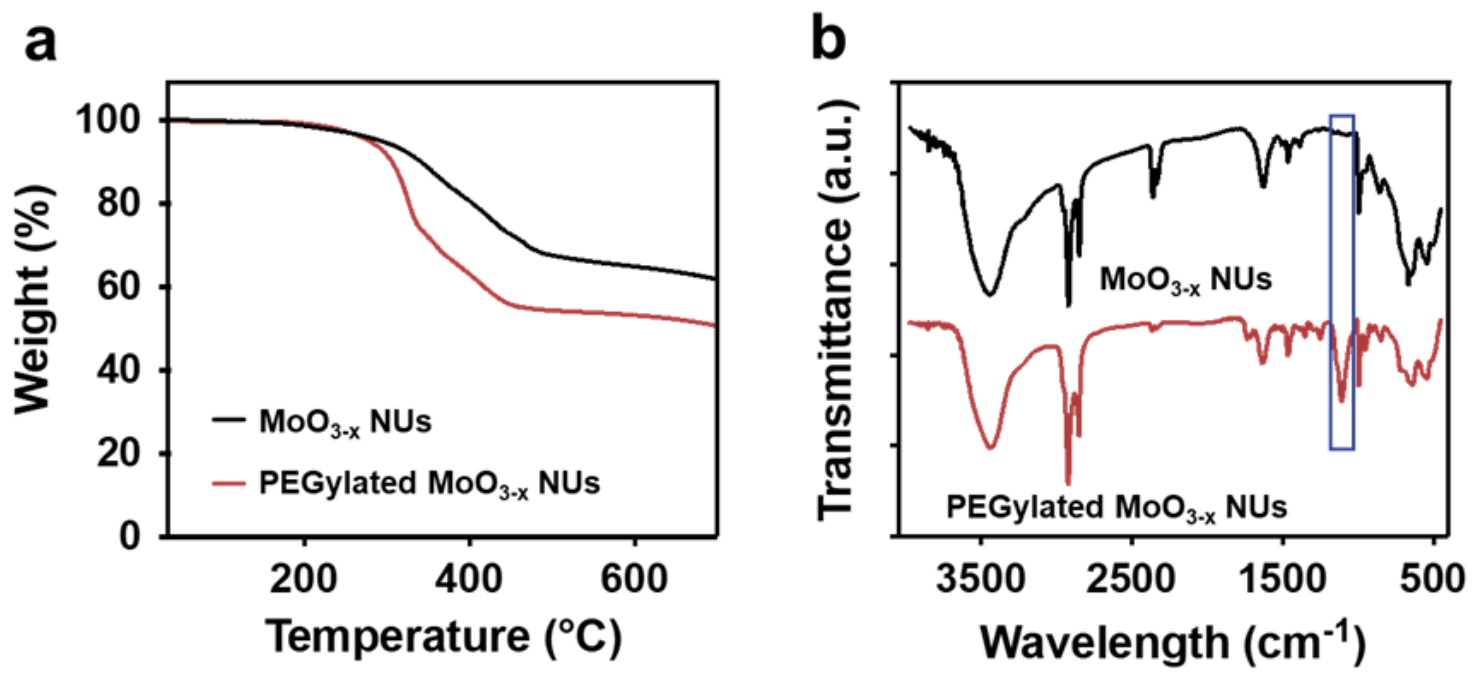

Figure S5. (a) TGA curves and (b) Fourier transform infrared (FT-IR) spectra of $\mathrm{MoO}_{3-\mathrm{x}}$ NUs and PEGylated $\mathrm{MoO}_{3-\mathrm{x}}$ NUs. The weight loss in TGA curves indicates the existence of DSPE$\mathrm{PEG}_{2000}$ molecules on the surface of $\mathrm{MoO}_{3-\mathrm{x}} \mathrm{NUs}^{4}$ Besides, the attachment of PEG to $\mathrm{MoO}_{3-\mathrm{x}}$ NUs is further verified by the peaks at $1116 \mathrm{~cm}^{-1}(\mathrm{C}-\mathrm{O}-\mathrm{C}$ stretching), which are attributed to amorphous PEG. ${ }^{5}$ 
a

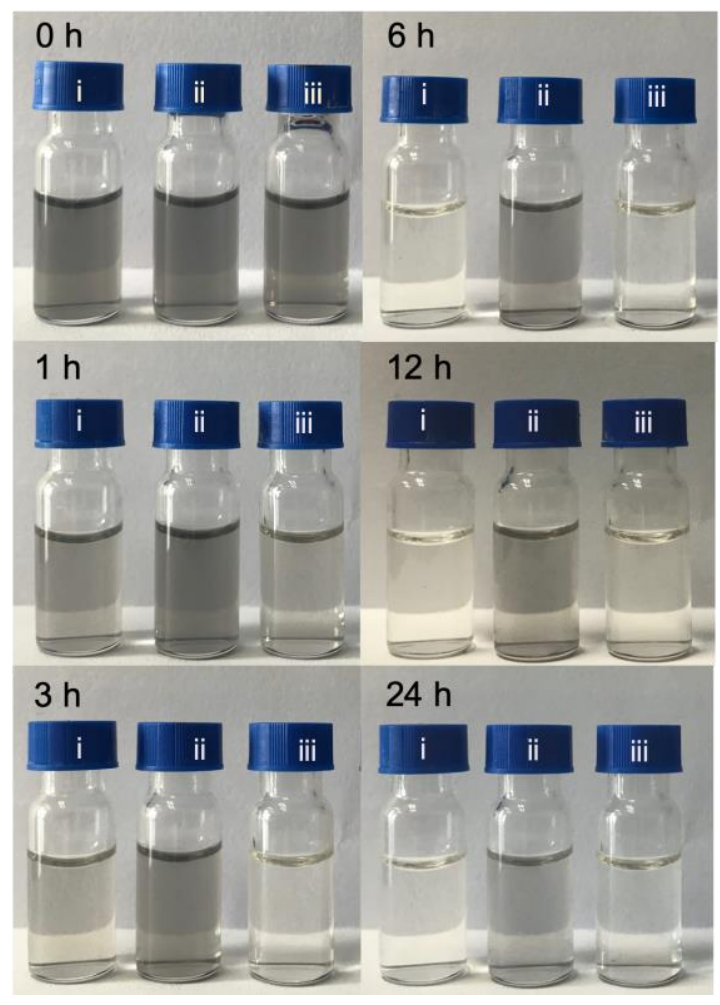

b

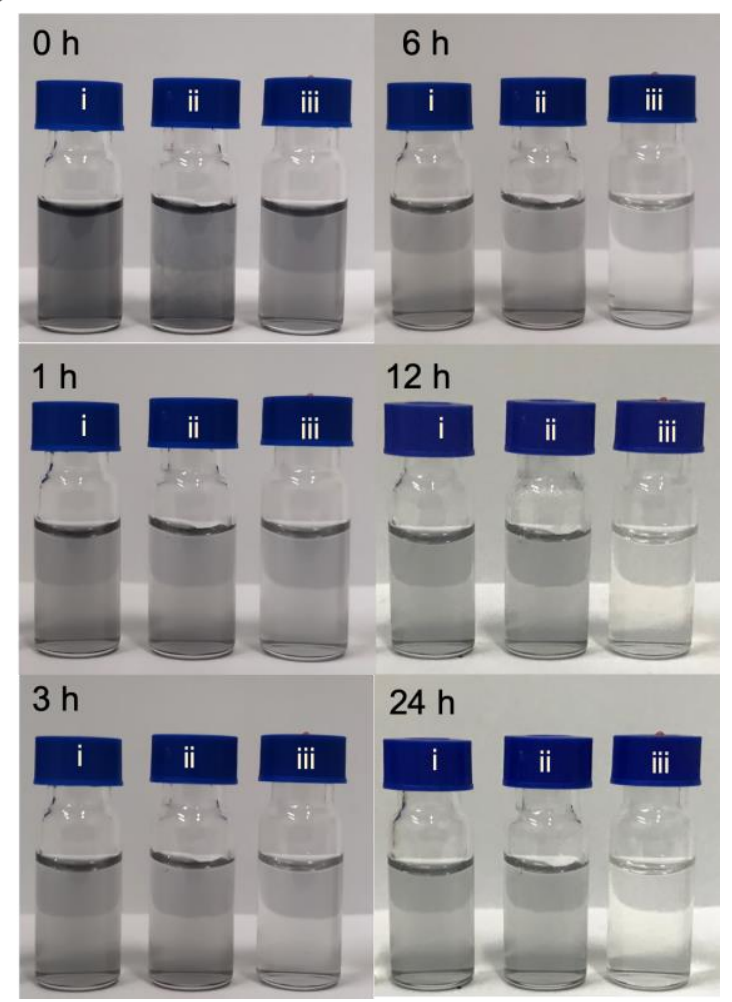

Figure S6. Photos of $\mathrm{MoO}_{3-\mathrm{x}} \mathrm{NUs}$ in (a) $\mathrm{PBS}$ (i, $\mathrm{pH}$ 7.4; ii, $\mathrm{pH}$ 6.0; iii, $\mathrm{pH}$ 8.5) and (b) various concentrations of $\mathrm{H}_{2} \mathrm{O}_{2}$ (i, $0.1 \mathrm{mM}$; ii, $1 \mathrm{mM}$; iii, $10 \mathrm{mM}$ ) in PBS (pH 6.0) at various time points.

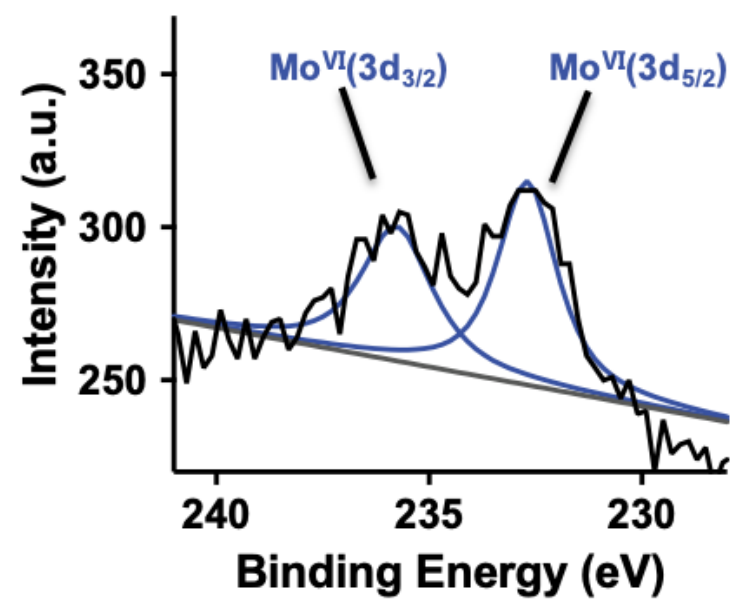

Figure S7. The Mo XPS spectrum of $\mathrm{MoO}_{3-\mathrm{x}}$ NUs degradation products (NUDPs). 


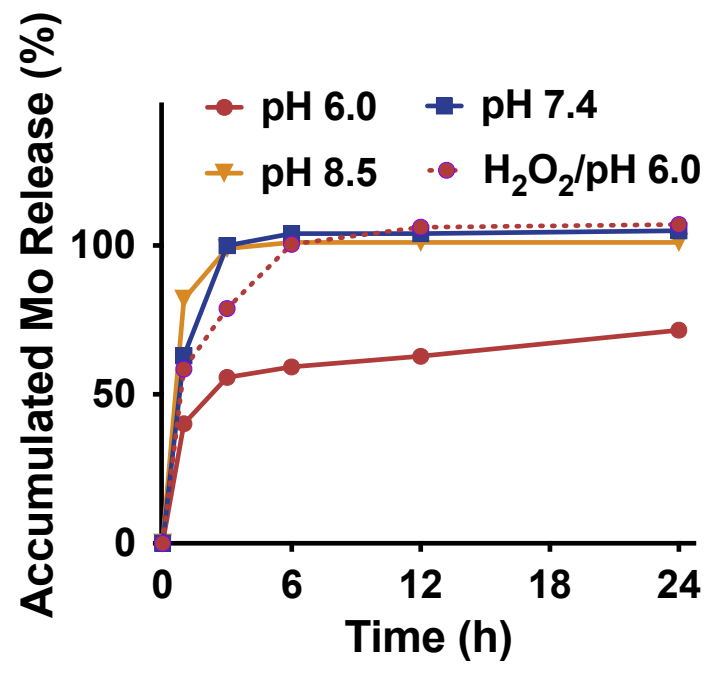

Figure S8. The accumulated Mo ion release in PBS (pH 6.0, $\mathrm{pH} 7.4$, and $\mathrm{pH} 8.5)$ and $1 \mathrm{mM}$ $\mathrm{H}_{2} \mathrm{O}_{2} / \mathrm{PBS}(\mathrm{pH} 6.0)$.
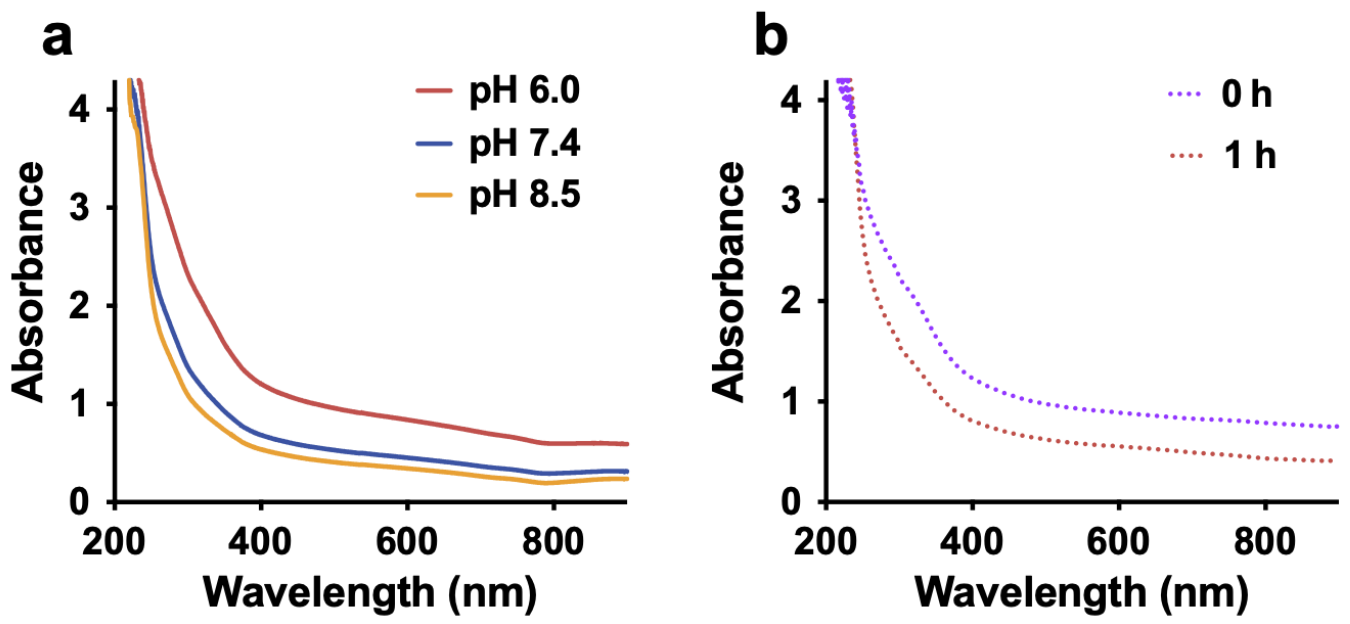

Figure S9. UV-Vis-NIR absorbance spectra of $\mathrm{MoO}_{3-\mathrm{x}} \mathrm{NUs}$ after incubation in (a) PBS (pH 6.0, $\mathrm{pH} 7.4$, and $\mathrm{pH} 8.5$ ) at $1 \mathrm{~h}$, and (b) $1 \mathrm{mM} \mathrm{H}_{2} \mathrm{O}_{2} / \mathrm{PBS}(\mathrm{pH} \mathrm{6.0)} \mathrm{at} 0 \mathrm{~h}$ and $1 \mathrm{~h}$. 

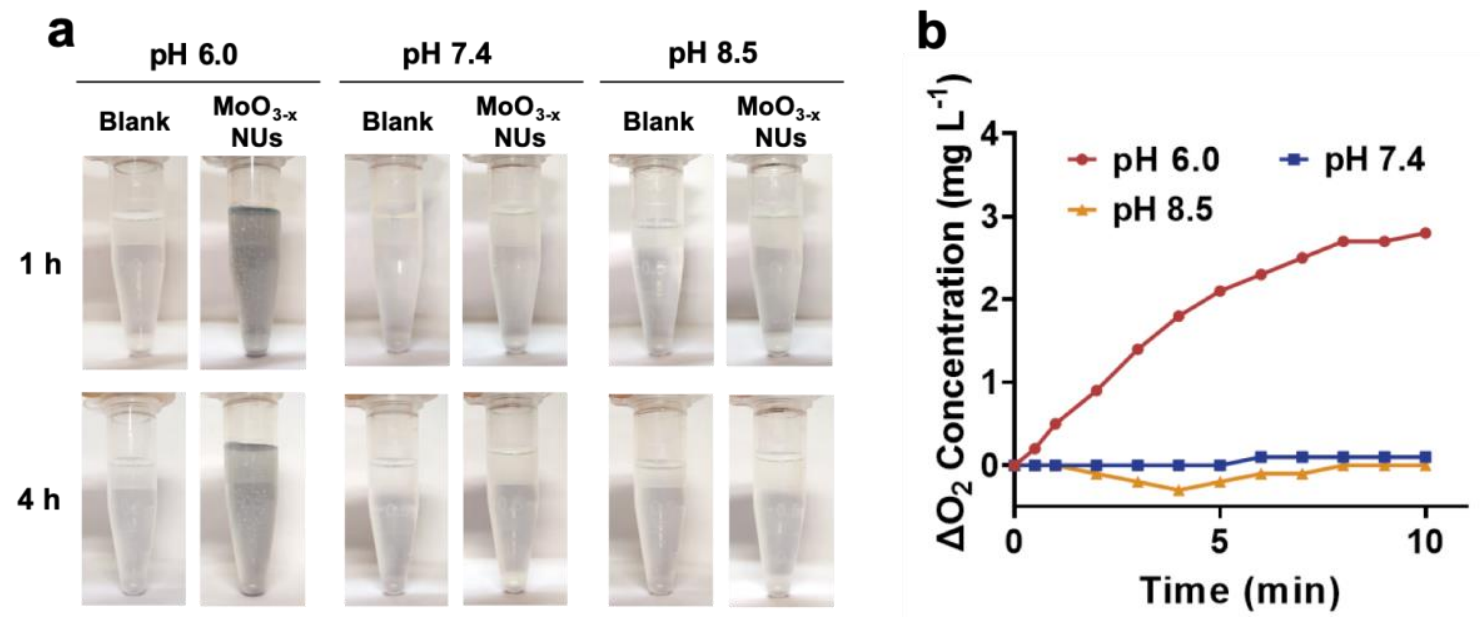

Figure S10. (a) Photographs of the $\mathrm{O}_{2}$ bubbles and (b) the $\mathrm{O}_{2}$ generation ability of $\mathrm{MoO}_{3-\mathrm{x}} \mathrm{NUs}$ under the condition of $\mathrm{H}_{2} \mathrm{O}_{2}(1 \mathrm{mM})$ in different $\mathrm{pH}$ values ( $\mathrm{pH}$ 6.0, $\mathrm{pH} 7.4$, and $\mathrm{pH}$ 8.5).
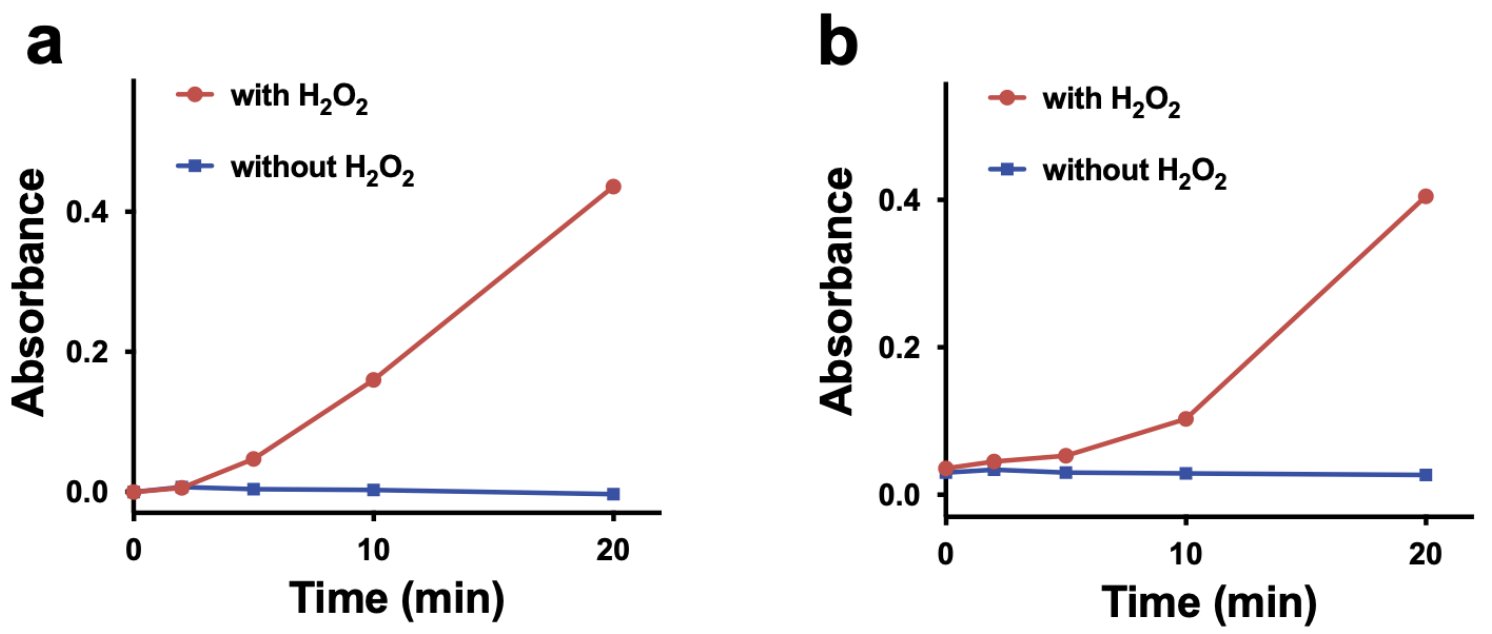

Figure S11. Absorbance changes in the presence of $\mathrm{MoO}_{3-\mathrm{x}} \mathrm{NUs}$ and (a) o-phenylenediamine (OPD) or (b) 3,3',5,5' -tetramethylbenzidine (TMB) with or without $4 \mu \mathrm{L}$ of $\mathrm{H}_{2} \mathrm{O}_{2}$ (1 M). 
a

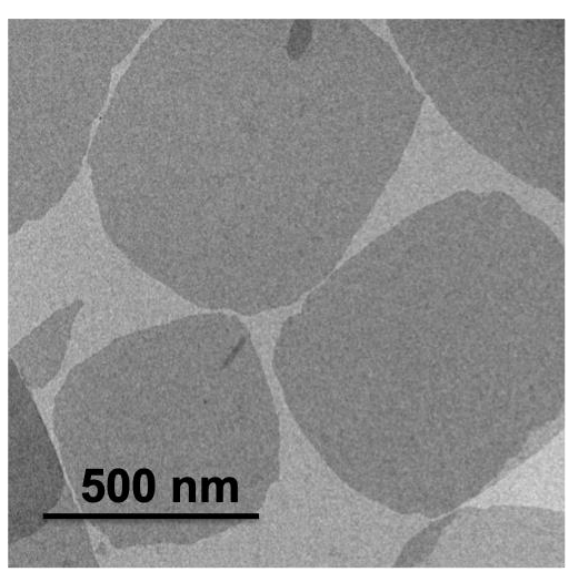

b

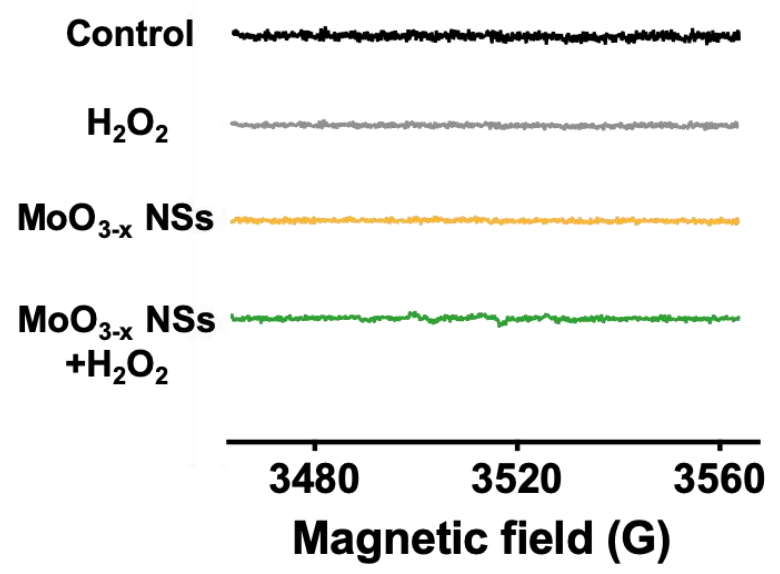

Figure S12. (a) The TEM image of $\mathrm{MoO}_{3-\mathrm{x}}$ nanosheets (NSs) and (b) electron spin resonance (ESR) spectra of $\mathrm{MoO}_{3-\mathrm{x}} \mathrm{NSs}$ in the presence of 5-tert-butoxycarbonyl-5-methyl-1-pyrroline $\mathrm{N}$-oxide (BMPO) and $\mathrm{H}_{2} \mathrm{O}_{2}(1 \mathrm{mM})$.

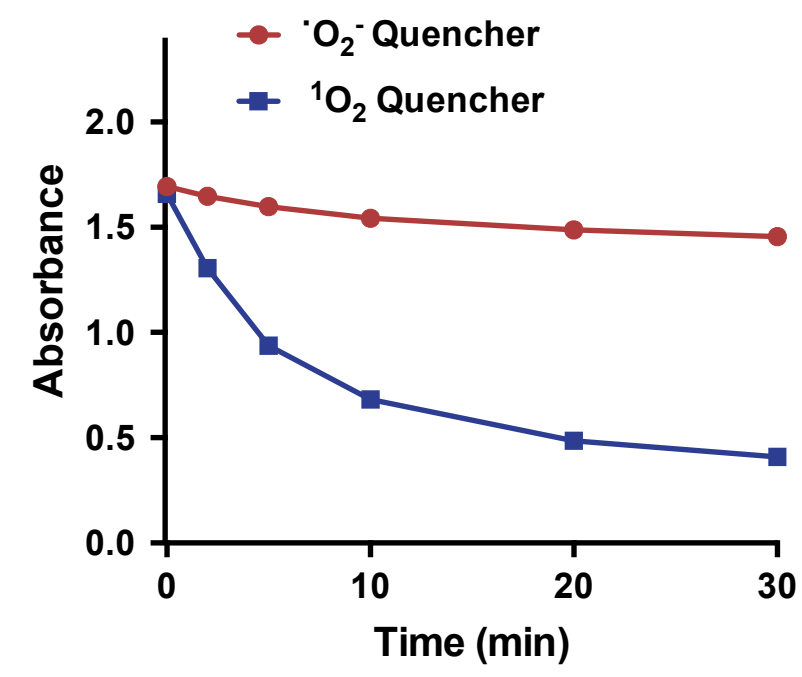

Figure S13. UV-Vis absorbance of 1,3-diphenylisobenzofuran (DPBF) in distilled water/ethanol solutions with $\mathrm{MoO}_{3-\mathrm{x}} \mathrm{NUs}$ and a scavenger $\left(\mathrm{O}_{2}^{-}\right.$scavenger: superoxide dismutase; ${ }^{1} \mathrm{O}_{2}$ scavenger: carotene) (Mo, $20 \mu \mathrm{g} ; \lambda=410 \mathrm{~nm}$ ). The decrease in absorbance of DPBF is significantly inhibited by superoxide dismutase rather than carotene, suggesting the ROS produced by $\mathrm{MoO}_{3-\mathrm{x}} \mathrm{NUs}$ once exposed upon excess $\mathrm{H}_{2} \mathrm{O}_{2}$ is mainly ${ }^{\circ} \mathrm{O}_{2}{ }^{-}$. 


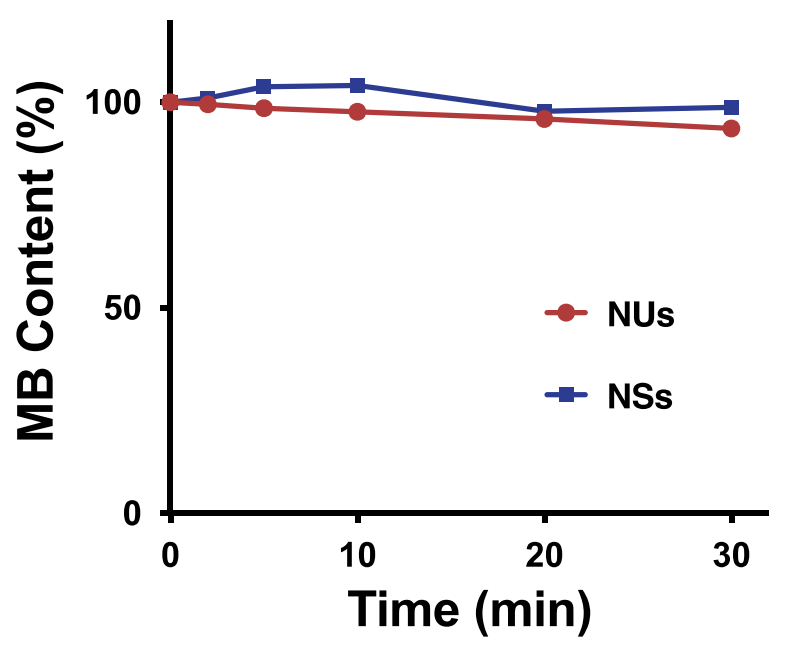

Figure S14. UV-Vis absorbance of methylene blue (MB) in the presence of $\mathrm{MoO}_{3-\mathrm{x}}$ NUs or $\mathrm{MoO}_{3-\mathrm{x}} \mathrm{NSs}(\lambda=663 \mathrm{~nm})$. No obvious degradation of MB is observed, indicating that neither $\mathrm{MoO}_{3-\mathrm{x}} \mathrm{NUs}$ nor $\mathrm{MoO}_{3-\mathrm{x}} \mathrm{NSs}$ catalyze the generation of $\cdot \mathrm{OH}$.

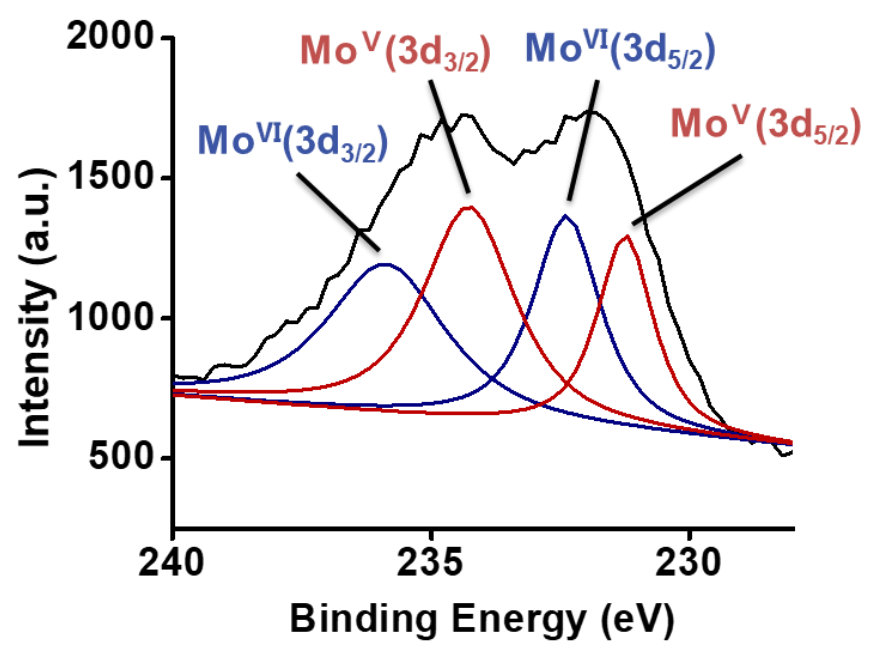

Figure S15. The Mo XPS spectrum of $\mathrm{MoO}_{3-\mathrm{x}} \mathrm{NUs}$ incubated with $1 \mathrm{mM} \mathrm{H}_{2} \mathrm{O}_{2}$ for $1 \mathrm{~h}$. 

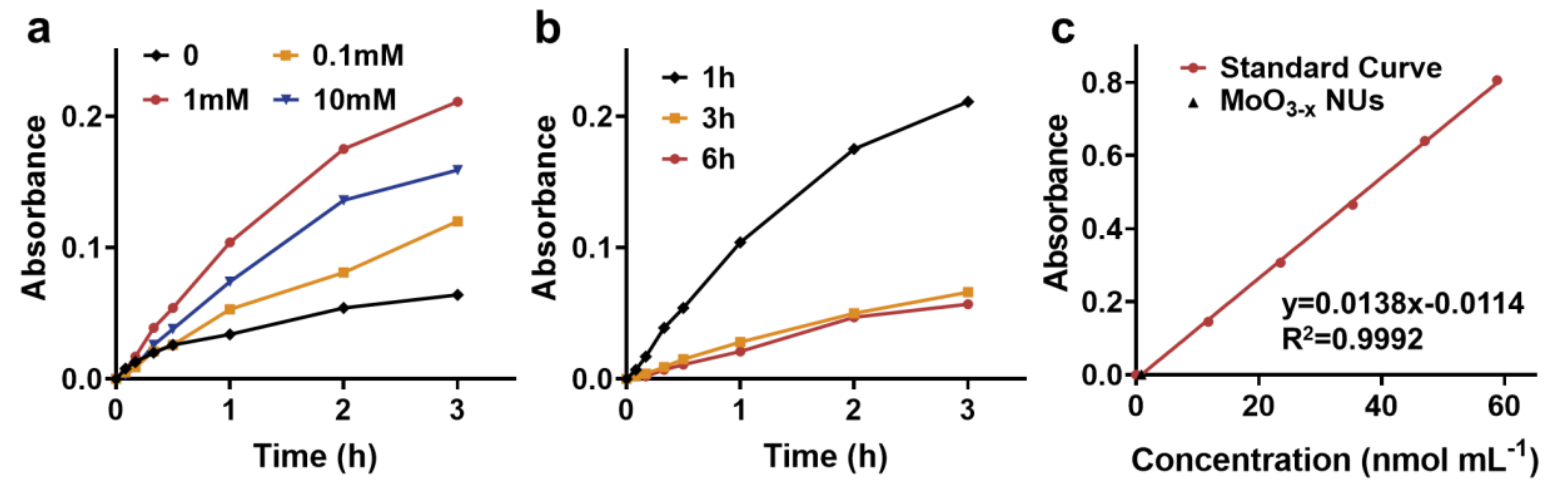

Figure S16. OXD-like activity of $\mathrm{MoO}_{3-\mathrm{x}}$ NUs. Absorbance changes $(\lambda=450 \mathrm{~nm})$ in the presence of OPD and $\mathrm{MoO}_{3-\mathrm{x}} \mathrm{NUs}$ that incubated with (a) $\mathrm{H}_{2} \mathrm{O}_{2}(0 \mathrm{mM}, 0.1 \mathrm{mM}, 1 \mathrm{mM}$, and $10 \mathrm{mM}$ ) for $1 \mathrm{~h}$, and (b) $1 \mathrm{mM} \mathrm{H} \mathrm{H}_{2} \mathrm{O}_{2}$ for $1 \mathrm{~h}, 3 \mathrm{~h}$, and $6 \mathrm{~h} . \mathrm{H}_{2} \mathrm{O}_{2}$ was removed before the OXDlike activity test, as verified by (c) the standard curve of $\mathrm{H}_{2} \mathrm{O}_{2}$ concentration $(\lambda=560 \mathrm{~nm})$. The amount of residual $\mathrm{H}_{2} \mathrm{O}_{2}$ in $\mathrm{MoO}_{3-\mathrm{x}} \mathrm{NUs}$ is below the limit of quantification $\left(2 \mathrm{nmol} \mathrm{mL} \mathrm{mL}^{-1}\right.$ ), indicating the successful remove of residual $\mathrm{H}_{2} \mathrm{O}_{2}$.

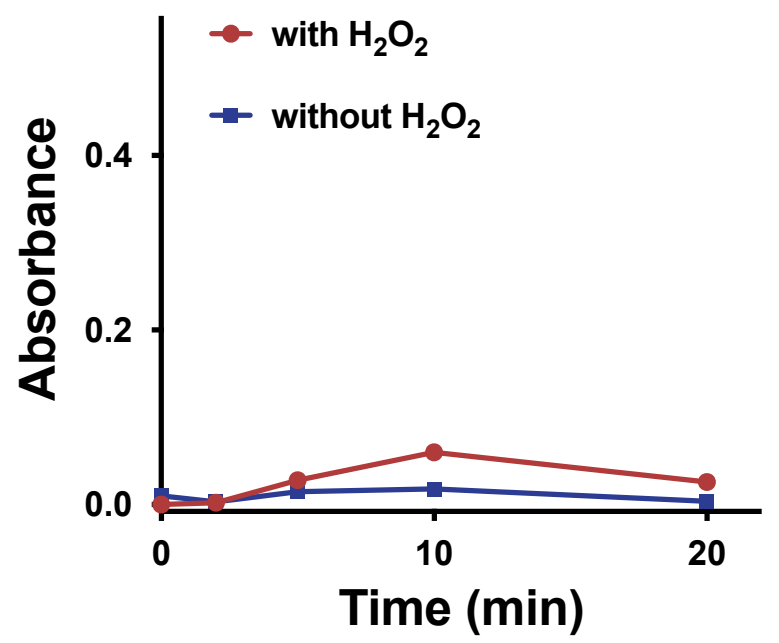

Figure S17. Absorbance changes in the presence of $\mathrm{MoO}_{3-\mathrm{x}} \mathrm{NSs}$ and TMB with or without 4 $\mu \mathrm{L}$ of $\mathrm{H}_{2} \mathrm{O}_{2}(1 \mathrm{M})$. 


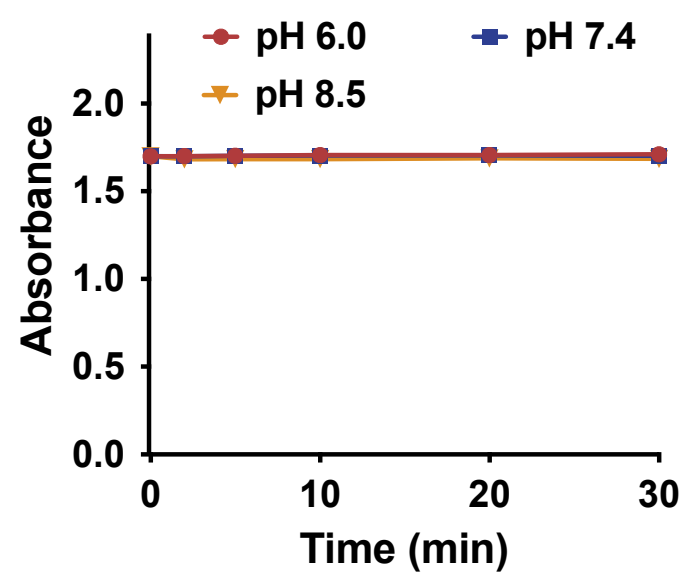

Figure S18. UV-Vis absorbance of DPBF in PBS $(\mathrm{pH} 6.0, \mathrm{pH} \mathrm{7.4}$, and $\mathrm{pH}$ 8.5)/ethanol solutions as controls $(\lambda=410 \mathrm{~nm})$, indicating $\mathrm{pH}$ has no influence on the degradation of $\mathrm{H}_{2} \mathrm{O}_{2}$.
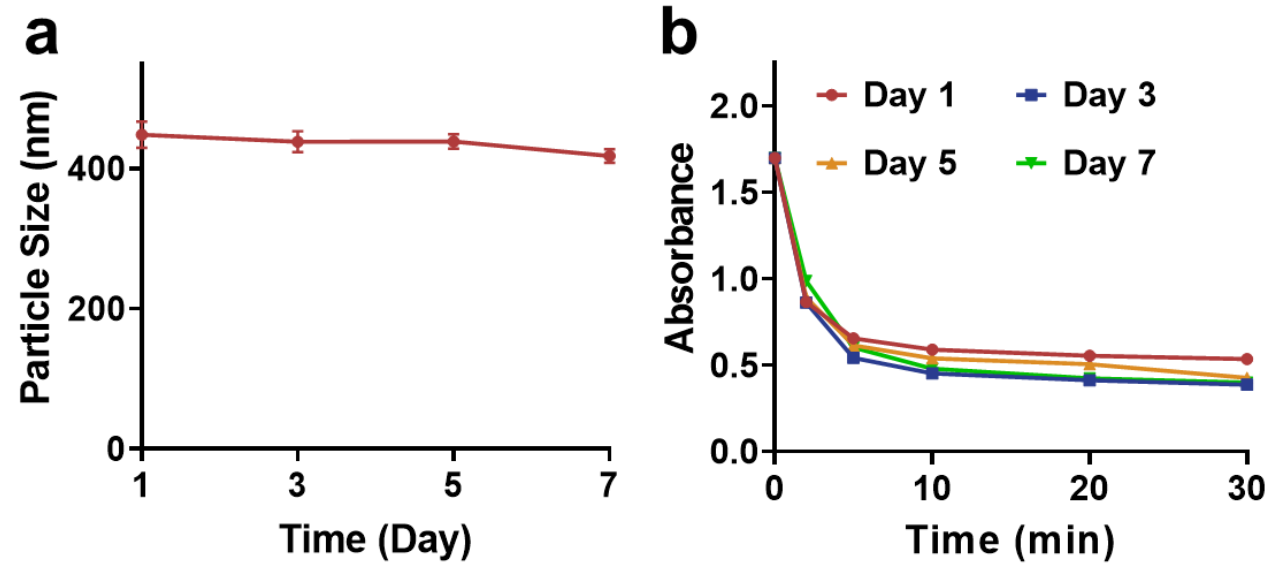

Figure S19. (a) Particle size changes and (b) ${ }^{\cdot} \mathrm{O}_{2}{ }^{-}$generation ability of $\mathrm{MoO}_{3-\mathrm{x}}$ NUs after storage in distilled water $\left(1 \mathrm{mg} \mathrm{mL}^{-1}\right)$ for $1 \mathrm{~d}, 3 \mathrm{~d}, 5 \mathrm{~d}$, and $7 \mathrm{~d}$. The results demonstrate that $\mathrm{MoO}_{3-\mathrm{x}}$ NUs can remain stable in distilled water for $7 \mathrm{~d}$. 


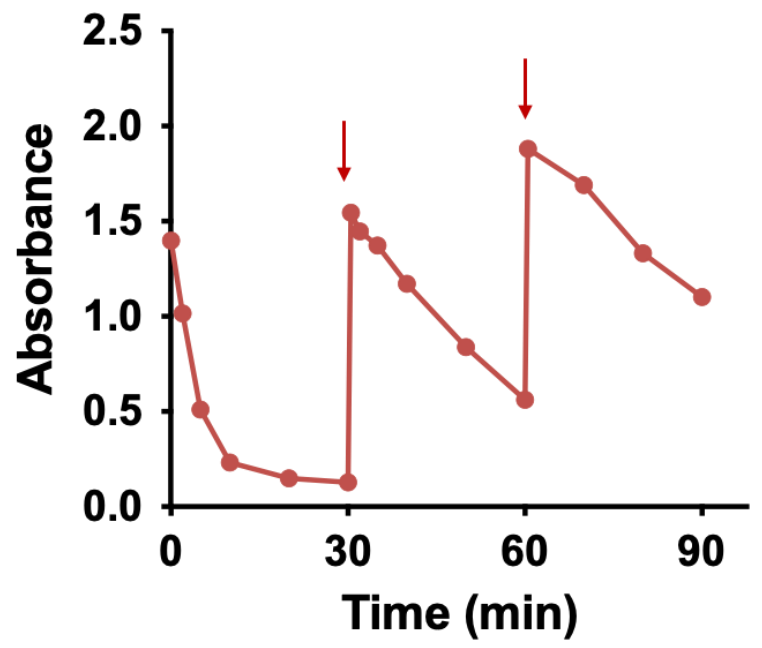

Figure S20. Reusability of $\mathrm{MoO}_{3-\mathrm{x}}$ NUs. UV-Vis absorbance of DPBF demonstrates $\mathrm{MoO}_{3-\mathrm{x}}$ NUs maintain enzymatic activity for at least three cycles.

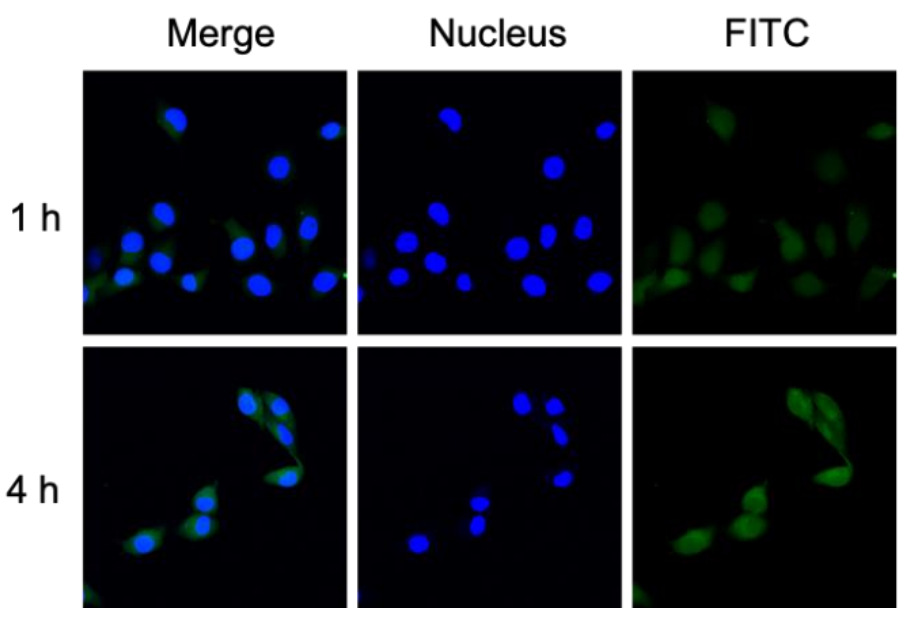

Figure S21. Representative confocal laser scanning microscopic (CLSM) images of B16 tumor cells after incubation with DMEM (pH 6.0) containing $\mathrm{MoO}_{3-\mathrm{x}} \mathrm{NSs} / \mathrm{FITC}$ for $1 \mathrm{~h}$ and $4 \mathrm{~h}$. 


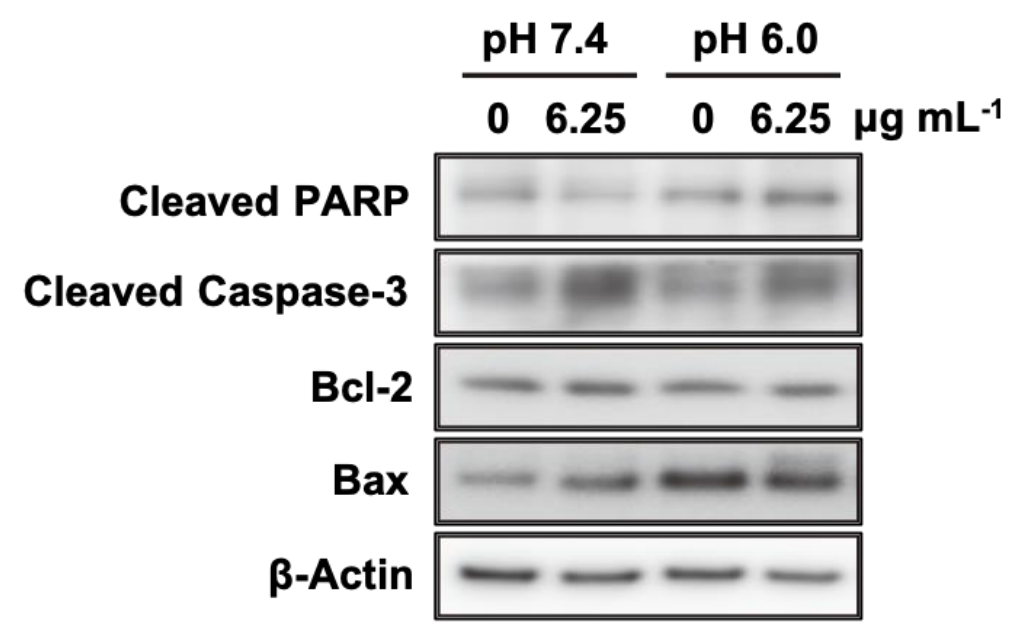

Figure S22. Effects of $\mathrm{MoO}_{3-\mathrm{x}} \mathrm{NSs}$ on the expression of cleaved PARP, cleaved caspase-3, Bax, and Bcl-2.

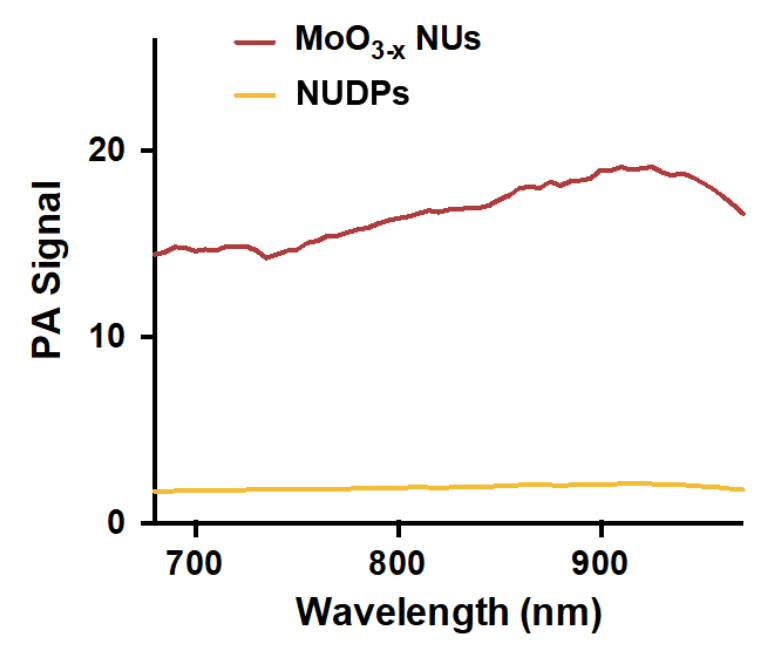

Figure S23. PA spectra of $\mathrm{MoO}_{3-\mathrm{x}}$ NUs and NUDPs at the range from $680 \mathrm{~nm}$ to $970 \mathrm{~nm}$. 


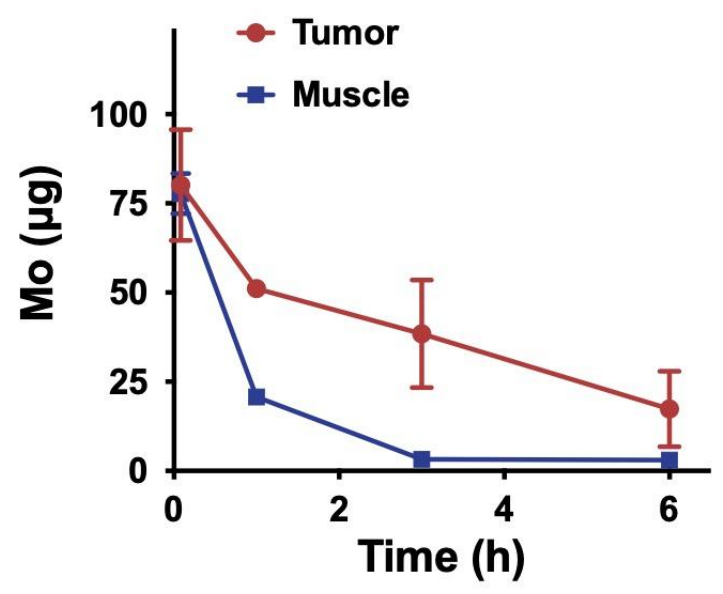

Figure S24. Mo levels in the tumor and the muscle of BALB/c nude mice harboring the B16 tumor xenograft at $5 \mathrm{~min}, 1 \mathrm{~h}, 3 \mathrm{~h}$, and $6 \mathrm{~h}$ post in situ injection of $\mathrm{MoO}_{3-\mathrm{x}} \mathrm{NUs}$.
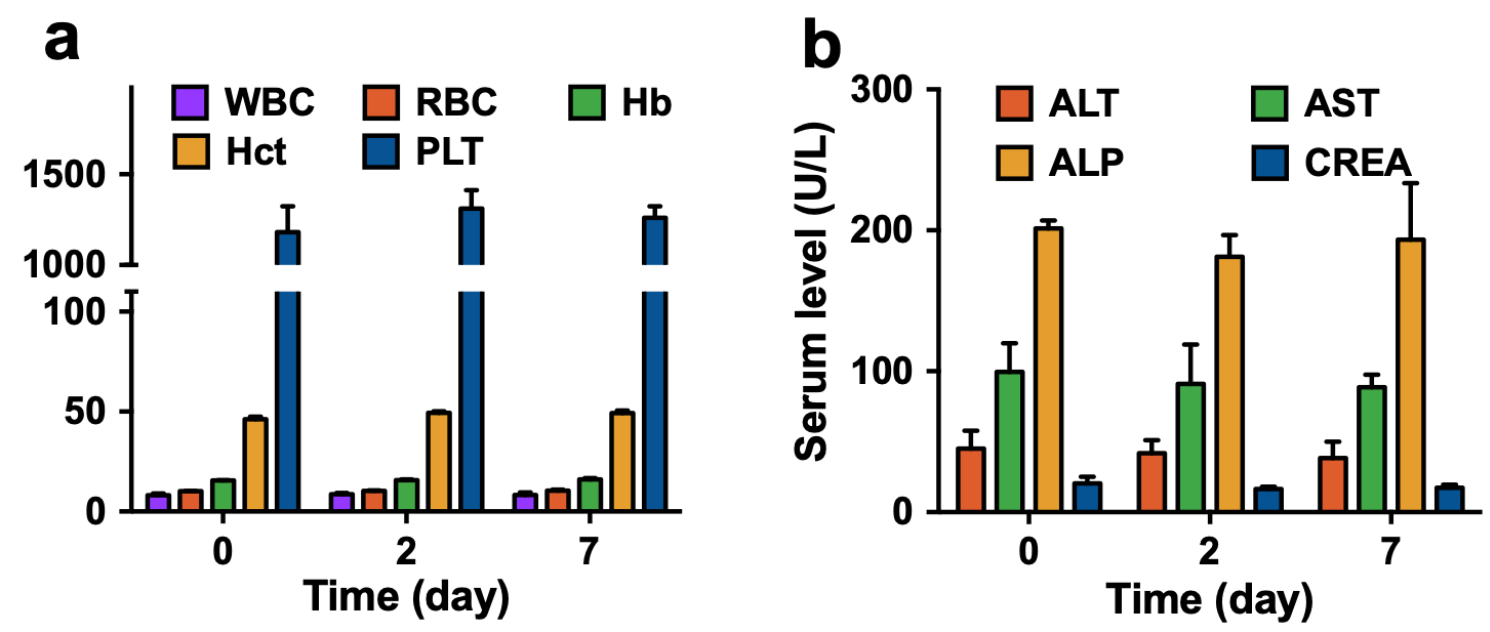

Figure S25. (a) Hematology data including white blood cells $\left(10^{9} \mathrm{~L}^{-1}\right.$, WBC), red blood cells $\left(10^{12} \mathrm{~L}^{-1}, \mathrm{RBC}\right)$, hemoglobin $(\mathrm{g} \mathrm{L}-1, \mathrm{Hb})$, hematocrit $\left(\%\right.$, Hct), platelets $\left(10^{9} \mathrm{~L}^{-1}, \mathrm{PLT}\right)$ of mice at $0 \mathrm{~d}, 2 \mathrm{~d}$, and $7 \mathrm{~d}$ post intramuscular injection with $\mathrm{MoO}_{3-\mathrm{x}} \mathrm{NUs}(\mathrm{n}=6)$. (b) Blood biochemical tests including alanine aminotransferase (ALT), aspartate aminotransferase (AST), alkaline phosphatase (ALP), and creatinine (CREA) on mice at $0 \mathrm{~d}, 2 \mathrm{~d}$, and $7 \mathrm{~d}$ post intramuscular injection with $\mathrm{MoO}_{3-\mathrm{x}} \mathrm{NUs}(\mathrm{n}=6$ ). The result implies the tissue toxicity caused by the possible leakage is negligible. 


\section{References}

(1) Song, G.; Hao, J.; Liang, C.; Liu, T.; Gao, M.; Cheng, L.; Hu, J.; Liu, Z. Degradable molybdenum oxide nanosheets with rapid clearance and efficient tumor homing capabilities as a therapeutic nanoplatform. Angew. Chem. Int. Ed. 2016, 55, 2122-2126.

(2) Zhang, C.; Bu, W.; Ni, D.; Zuo, C.; Cheng, C.; Li, Q.; Zhang, L.; Wang, Z.; Shi, J. A polyoxometalate cluster paradigm with self-adaptive electronic structure for acidity/reducibility-specific photothermal conversion. J. Am. Chem. Soc. 2016, 138, 81568164.

(3) Song, G.; Shen, J.; Jiang, F.; Hu, R.; Li, W.; An, L.; Zou, R.; Chen, Z.; Qin, Z.; Hu, J. Hydrophilic molybdenum oxide nanomaterials with controlled morphology and strong plasmonic absorption for photothermal ablation of cancer cells. ACS Appl. Mater. Interfaces $\mathbf{2 0 1 4}, 6,3915-3922$.

(4) Hu, X.; Sun, J.; Li, F.; Li, R.; Wu, J.; He, J.; Wang, N.; Liu, J.; Wang, S.; Zhou, F.; Sun, X.; Kim, D.; Hyeon, T.; Ling, D. Renal-clearable hollow bismuth subcarbonate nanotubes for tumor targeted CT imaging and chemoradiotherapy. Nano Lett., 2018, 18, 1196-1204.

(5) Kamiar, Z.; Hamed, V.; Mahmoud, M.; Mahmoud, A.; Somayeh, Y.; Jafar, B.; Ali, M.; Saba, H.; Hojat, V. Modified magnetic nanoparticles by PEG-400 immobilized Ag nanoparticles $\left(\mathrm{Fe}_{3} \mathrm{O}_{4} @ \mathrm{PEG}-\mathrm{Ag}\right)$ as a core/shell nanocomposite and evaluation of its antimicrobial activity. Int. J. Nanomedicine, 2018, 13, 3965-3973. 